\title{
Oh, father, where art we? Left internal mammary artery with greater saphenous vein grafts still rules surgical coronary revascularization after $\mathbf{3 0}$ years
}

\author{
Chadwick W. Stouffer, MD, and Michael E. Halkos, MD, MSc
}

\footnotetext{
From the Division of Cardiothoracic Surgery, Joseph B. Whitehead Department of Surgery, Emory University School of Medicine, Atlanta, Ga.

Disclosures: Authors have nothing to disclose with regard to commercial support.

Received for publication Dec 6, 2017; accepted for publication Dec 18, 2017; available ahead of print Jan 10 , 2018.

Address for reprints: Chadwick W. Stouffer, MD, 550 Peachtree St NE, 6th floor, Atlanta, GA 30308 (E-mail: cstouff@emory.edu).

J Thorac Cardiovasc Surg 2018; 155:2329-30

$0022-5223 / \$ 36.00$

Copyright (c) 2017 by The American Association for Thoracic Surgery https://doi.org/10.1016/j.jtcvs.2017.12.069
}

To answer the question, "where are we and where are we going?," we must first look at where we have been. Bakaeen and colleagues ${ }^{1}$ answer that question well in this historical review commemorating the 50th anniversary of Dr Rene Favaloro's monumental performance of his first coronary artery bypass grafting (CABG) operation. As part of this historical review, we are reminded not only of Dr Favaloro's contributions to the surgical treatment of coronary artery disease, but also of the contributions of many other pioneers of coronary revascularization.

In the wake of accidentally, but fortuitously, performing the first coronary angiogram, Dr F. Mason Soles Jr, along with Dr Favoloro, set the stage for the current collaborative model of cardiovascular care. Dr Favaloro reflected on this in 1999: "I am pleased to see that at present, the devastating effects of AMI have been ameliorated by the combined efforts of the clinician, the interventional cardiologist, and the cardiovascular surgeon.", 2 Their approach to patient care was the first "heart team" approach long before the concept of multidisciplinary treatment teams gained traction and popularity. We rely on this model heavily today and will continue to rely on it in the future to ensure delivery of the best and most advanced care to our patients. Structural heart disease seems to have taken the lead in this arena with valvular heart disease, but treatment of coronary artery disease is close behind, with the advent of heart teams for the management of patients with coronary artery disease. Furthermore, surgeons and interventionalists continue to refine their approaches for treating coronary disease, including the use of multiple arterial grafts, percutaneous treatment of chronic total occlusions, minimally invasive $\mathrm{CABG}$, and hybrid coronary revascularization. Dr Favaloro's fingerprints remain evident on this hybrid procedure in the form of left internal mammary artery (LIMA) to left anterior descending artery (LAD) grafting, a technique that he care in $1986 .^{3}$ saphenous vein. outcomes.

\section{References}

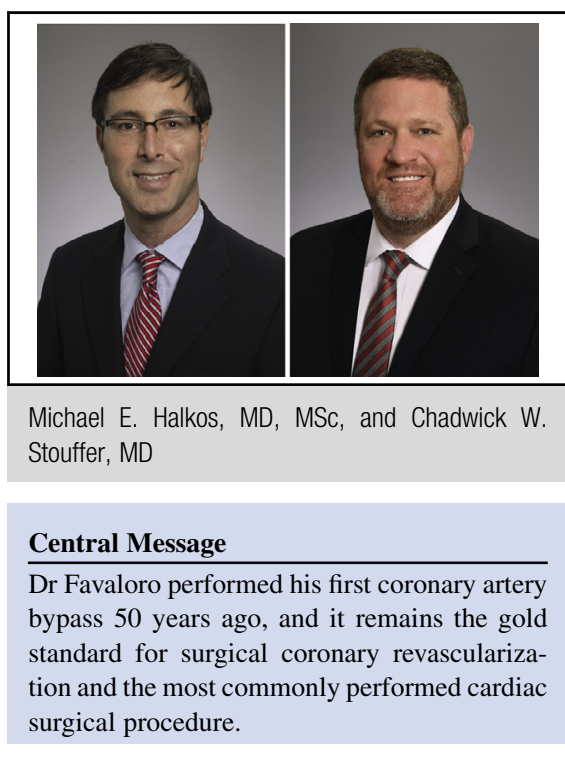

See Article page 2324.

pioneered and his colleagues solidified as the standard of

Today, 50 years later, Dr Favaloro retains the title of "father of CABG." His standardized operation, including the LIMA to the LAD, allows for reliable performance of CABG with impressively low rates of morbidity and mortality. Despite the plethora of research into multiple arterial conduits, today CABG with a LIMA to LAD graft and multiple saphenous vein grafts still reigns as king of surgical revascularization. In the United States, the rate of bilateral internal mammary artery use for $\mathrm{CABG}$ is $<10 \%$, and $>80 \%$ of all bypass grafts are performed with greater

As surgeons, just as Dr Favaloro did, we must constantly examine our practice and our patient population to optimize treatments, interventions, and surgical techniques. As his progeny, our mission is to use his innovation, perfection, and collaborative attitude to carry coronary revascularization into the next generation while continuing to improve

1. Bakaeen FG, Blackstone EH, Pettersson GB, Gillinov AM, Svensson LG. The father of coronary artery bypass grafting: Rene Favaloro and the 50th anniversary of CABG. J Thorac Cardiovasc Surg. 2018;155:2324-8. 
2. Favaloro RG. Acute coronary insufficiency: impending myocardial infarction and acute myocardial infarction. J Am Coll Cardiol. 1999;33:1435-41.

3. Loop FD, Lytle BW, Cosgrove DM, Stewart RW, Goormastic M, Williams GW, et al. Influence of the internal mammary artery graft on 10-year survival and other cardiac events. $N$ Eng J Med. 1986; 314:1-6.

4. Head SJ, Milojevic M, Taggart DP, Puskas JD. Current practice of state-of-the-art surgical coronary revascularization. Circulation. 2017;136:1331-45. 